\title{
In vitro and In vivo Assessment of Banana Peel Powder as an Aflatoxins Biosorbent
}

\author{
Dalia M.I. Ali( ${ }^{(1) \#}$, Tahany M. Abdel-Rahman ${ }^{(1)}$, Amel A. Abo-hagger ${ }^{(2)}$, Mona S. \\ Ahmed ${ }^{(2)}$ \\ (1) Botany and Microbiology Department, Faculty of Science, Cairo University, Giza, \\ Egypt; (2)Regional Center for Food and Feed, Agriculture Research Center (ARC), \\ Giza, Egypt.
}

\begin{abstract}
QURVEY of fungi in raw peanut seeds by washing technique method resulted in isolation of nine fungal species. The aflatoxigenic Aspergillus flavus was the most frequently isolated species in the isolation plates. Molecular identification confirms that it is identical to A. flavus available in database in NCBI GenBank with similarity of $100 \%$. The aflatoxins (AFs) produced in the fermentation medium of $A$. flavus were extracted and estimated by HPLC to be contain B1, B2, G1, G2 AFs. Banana peel powder, prepared from samples collected from juice markets, proved to be of high adsorption capacity to aflatoxins in concentration depending manner of either peel or aflatoxins.

In vivo histopathological studies using 6 albino rats groups, an alteration in rats treated with single aflatoxin concentrations (G2 or G3) such as inflammation, fibrosis, expanded portal tract and degeneration of hepatocytes in liver and expanded glomeruli, vacuolation $\&$ fatty degeneration in renal tubules were detected in kidney. However, banana peel treated singly showing normal hepatocytes and central vein in liver as well as normal tubules and glomeruli in kidney. Co-addition of AFs with banana peel powder to rat diet showing significant reduction in the harmful effect of AFs added singly in liver and kidney tissues. This study indicated also that the liver was highly affected by AFs than kidney.
\end{abstract}

Keywords: Aflatoxins, Banana peel, Albino rats, Adsorption, Histopathology, Agricultural wastes.

\section{Introduction}

Peanut (Arachis hypogaea L.) is belonging to Family Fabaceae. Egypt is a major exporting country of peanut and the European markets account for $68 \%$ of its exports. In May, 1999 the European Commission suspended the import of peanuts from Egypt due to the presence of aflatoxins in concentrations exceeding the safe levels specified in the EU regulations.

Many soil borne fungi are serious pathogens of pod and seeds in the field and many storage fungi infect peanut during storage and transportation. This causing pod and seeds rot and their invasion caused various damages including yield loses in both quality and quantity of seeds, discoloration, decay and mycotoxin production. Peanuts are important substrates for the growth of mold and subsequent aflatoxins production by different species of Aspergillus (Abdel-Wahhab et al., 2011).

Mycotoxins are secondary metabolites which have low molecular weights and produced by mycelia or spores of filamentous fungi (Gonçalez et al., 2001). They are classified as the most important chronic, non-antigenic and noninfectious foodborne risk factor. They are more injurious than synthetic contaminants, plant toxins, food additives, and pesticide residues. Both humans and animals may show acute or chronic toxification caused by mycotoxin ingestion and the pathological condition results from this ingestion is called mycotoxicosis (Nierman et al., 2008).

Aflatoxins are the most toxic group of

"Corresponding author email: dibrahim@sci.cu.edu.eg 
mycotoxins that are produced by some Aspergillus species (Aspergillus flavus, A. parasiticus and the rare A. nomius) (Park et al., 2002). The International Cancer Research Institute identified aflatoxins (AFs) as class 1 carcinogens (Asim et al., 2011 and Prabu et al., 2013). AFB1 is the most potent genotoxic and carcinogenic form of AFs (Park et al., 2002). The risk of contamination by aflatoxins of food and feed in Africa is increased due to environmental, agronomic, socio-economic factors, temperature, food substrate, strain of the mold and other environmental factors that affect mycotoxin production (Guchi, 2015).

In recent years, using mycotoxin-adsorbing agents to bind mycotoxins in the gastrointestinal tract of animals lead to decrease their bioaccumulation, toxicities and bioavailability and results in promising improvement in feed industrial applications. Adsorption agents are very useful to prevent aflatoxicosis but may not very effective for adsorption of other mycotoxins (Cheng et al., 2016).

Agricultural wastes such as peel of various fruits and vegetables is applied in food and other industries as an adsorption agents for various contaminants (Mohamed et al., 1994). Peels of fruits and vegetables such as Mangifera indica, Solanum tuberosum, Lagenaria siceraria, Luffa acutangula, Ananas comosus, Momordica charantia, Carica papaya, Moringa oleifera, Raphanus sativa, Punica granatum, Chrysophyllum albidum have broad antitoxic activities (Kulkarni, 2005; Chanda et al., 2010; Kamba \& Hassan, 2010; Mohd et al., 2012 and Janjua et al., 2013). Furthermore, several plant wastes have been shown to have ameliorative effects against induced toxicity of AFB1 in animals (Liu et al., 1995; Gyamfi \& Aniya, 1998; Oluwafemi \& Taiwo, 2004; Farombi et al., 2005 and Choi et al., 2011).

Banana peels are agricultural waste that discarded allover the world as useless material, although, they have high adsorbent potentiality (Hossain et al., 2012). They are very useful for refining processes and purification. They have absorption capabilities for some elements and ions in liquid or solution, such as adsorption capacities to eliminate chromium from wastewater (Memon et al., 2008), copper (Hossain et al., 2012) in addition to some dyes (Velmurugan et al., 2011). It is abundantly available, low cost, and environment friendly bio-material. This agricultural waste is also cheap, inexhaustible and non-hazardous, and is specifically selective for heavy metals adsorption and can be easily disposed by incineration (Das et al., 2008). It could be used as similar to charcoal and activated charcoal as common adsorbent (Mopoung, 2008). The modification of banana and orange peels with acid treatment significantly improve color adsorption capacity as compared to raw banana and orange peels (Mane \& Bhusari, 2012). Banana peel has proven to be a promising material for the removal of contaminants from olive mill wastewaters by adsorption (Mandi et al., 2009). Zheng \&Wang (2013) concluded that banana peel containing functional groups as adsorbent which is responsible for the outstanding adsorption performance for $\mathrm{Au}$ (III). The alkaline fractions of peel were evaluated as a multi-functional antibacterial, dye adsorption, and UV protective agent on the cotton substrate (Salah, 2012 and Chabuck et al., 2013).

The objective of this study aimed to investigate the effect of banana peel as adsorbent agent to the aflatoxins produced from A. flavus in in vitro experiment as well as to study its potential to reduce the injurious effect on liver and kidney of albino rats, feed with AFs contaminated diet.

\section{$\underline{\text { Materials and Methods }}$}

\section{Fungal isolation from raw peanut}

Five grams from raw peanut sample, obtained from local markets, were disinfected using 2.5\% sodium hypochlorite for one minute, rinsed three times in $10 \mathrm{ml}$ sterile distilled water, dried and homogenized with $90 \mathrm{ml}$ of sterilized distilled water in stomacher for $2 \mathrm{~min}$. Serial dilutions of $10^{-1}, 10^{-2}$ and $10^{-3}$ were prepared from peanut suspension. Each dilution was shaken and $1 \mathrm{ml}$ aliquot was transferred onto surface of petridishes containing rose bengal chloramphenicol agar medium (NMKL Report, 2005). The dishes were rotated by hand to disperse on the surface of medium then incubated at $25^{\circ} \mathrm{C}$ for 7 days. The resulting colonies were counted, isolated and identified using standard identification manuals (Gilman, 1957; Barnett \& Hunter, 1972; Raper \& Fennell, 1965; Moubasher, 1993; Watanabe, 2002; Samson, 1979 and Samson et al., 1995, 2010). The identified fungal cultures were maintained $0 \mathrm{n}$ PDA medium (Shotwell et al., 1966). 
Molecular identification of the most frequent fungus

This experiment was carried out to confirm identification of the most frequent fungal species in isolation plates Aspergillusflavus which nuclear ribosomal DNA internal transcribed spacer (ITS) sequencing was used. DNA extracted by Quick-DNA ${ }^{\text {TM }}$ Fungal/Bacterial Micro prep Kit (Zymo research \#D6007) Then PCR was made by using Maxima Hot Start PCR Master Mix (Thermo K1051). GeneJETTM PCR Purification Kit (Thermo K0701) was used to clean up PCR product. Internal transcribed spacer (ITS) region of 5.8S rRNA was amplified using the primers ITS1 (5'TCCGTAGGTGAACCTGCGG3') and ITS4 (5'TCCTCCGCTTATTGATATGC 3'). Sequencing of PCR amplified product at GATC Company by use ABI 3730xl DNA sequencer using forward and reverse primers. Combining the traditional Sanger technology with the new 454 technologies. The closely related phylogenetic sequences were obtained after entering the resulting sequence into BLAST (Basic Local Alignment Search Tool) of the National Center for Biotechnology Information (NCBI) data base search program (http://WWW. ncbi.nlm.nih.gov/blast/). A phylogenetic tree was constructed using MEGA 6 software.

\section{Determination of aflatoxins concentration}

The concentration of AFs extracted from A. flavus fermentation medium as described by Abdel-Rahman et al. (2017) was determined using HPLC technique (Agilent 1200 Series U.S.A with column $\mathrm{C}_{18}$, Lichrospher $100 \mathrm{RP}-18$, $5 \mu \mathrm{m} \times 25 \mathrm{~cm})$. The mobile phase constituted of water: methanol: acetonitrile $(54: 29: 17, \mathrm{v} / \mathrm{v} / \mathrm{v})$ at flow rate of $1 \mathrm{ml} / \mathrm{min}$. The excitation and emission wavelengths for all aflatoxins were 362 and 460nm (Florescence detector), respectively, (Roos et al., 1997 and AOAC, 2016).

\section{In vitro adsorption capacity of AFs using banana peel powder}

Adsorption equilibrium experiments were carried out by adding $250,500,750,1000 \mu \mathrm{L}$ of A. flavus aflatoxins mother solution, then diluted to $100 \mathrm{ml}$ by distilled water in polyethylene bottle to obtain solutions having concentrations of $(1080,1158,1191.6$, and 1436.3ppb), respectively. Seven levels of the adsorbent banana peel powder, 0.0 (control) $0.5,1.0,1.5$, $2.0,2.5$, and $3.0 \% \mathrm{w} / \mathrm{v}$ distilled water, were added to each AFS diluted solutions which shake using horizontal shaker for 1 and $2 \mathrm{~h}$. The suspension was filtered and extracted with chloroform $(1: 2$, $\mathrm{v} / \mathrm{v}$ ) (Abd El-mageed, 1987) then evaporated until obtaining dry film in rotary evaporator. The obtained dry film containing AFs was reconstituted with water: methanol: acetonitrile $(54: 29: 17, \mathrm{v} / \mathrm{v} / \mathrm{v})$ the final concentration of aflatoxins in distilled water was measured using HPLC technique (Agilent1200 series).

Histopathological alterations under the effect of AFs singly or in combination with banana peel powder

Six groups of albino rats were used as shown in Table 1. Animal housing and treatment conditions were approved by the ethics committee that determines the ethical and animal welfare practices (approval number: $\mathrm{CU} /$ $1 / \mathrm{F} / 48 / 18)$.

Histopathological technique was performed according to the method of Bancroft \& Stevens (1996). Samples taken from liver and kidney preserved in neutral formalin solution $(10 \%$ $\mathrm{v} / \mathrm{v})$. The tissues were dehydrated in ascending grades of ethanol $(70 \%, 80 \%, 90 \%$ and absolute) two hours each. The tissues were immersed in xylene for two hours and this step was repeated once more, the tissues then immersed for two hours in a liquid wax (melting point $55 \pm 1^{\circ} \mathrm{C}$ ). Mounted in blocks of liquid paraffin and left to solidify in a cold temperature. Sections of $5-6 \mu \mathrm{m}$ thick were cut using a microtome and mounted on microscope slides. The slides were then immersed in xylene, rehydrated by descending grades of alcohol then water, immersed in Haematoxylin for $15 \mathrm{~min}$. Four dips in water, five dips in $1 \%$ acid alcohol, four dips in tap water, six dips in ammonia water solution, distilled water for $15 \mathrm{~min}$ were carried out. The sections were treated by Eosin stain for $1 \mathrm{~min}$, ascending grades of alcohol, and three changes of xylene $2 \mathrm{~min}$ for each change and finally mounted in Canada balsam. Tissue section was then examined using a light microscope for histological evaluation.

\section{Statistical analysis}

All data were done with three replications for each parameter. Estimates of LSD were calculated to test the significance differences among means according to Snedecor \& Cochran (1994) by using Duncan test institute program (Waller \& Duncan, 1969). 
TABLE 1. The experimental design used in the in vivo experiment.

\begin{tabular}{ll}
\hline Group1 (G1) & Basal diet (control) \\
Group2 (G2) & Received orally low dose of AFs (1 mg AFs suspended in 5ml DMSO/ kg B.W.) twice/week \\
Group3 (G3) & Received orally high dose of AFs (2mg AFs suspended in 5ml DMSO/ kg B.W.) twice/week \\
Group4 (G4) & $\begin{array}{l}\text { Received basal Diet supplemented with banana peel at level 3\% } \\
\text { Group5 (G5) }\end{array}$ \\
$\begin{array}{l}\text { Received orally low dose of AFs (1 } \mathrm{mg} \mathrm{AFs} \mathrm{suspended} \mathrm{in} \mathrm{5ml} \mathrm{DMSO/} \mathrm{kg} \mathrm{B.W.)} \mathrm{+3 \%} \mathrm{banana} \mathrm{peel} \mathrm{twice/} \\
\text { week } \\
\text { Group6 (G6) }\end{array}$ & $\begin{array}{l}\text { Received orally high dose of AFs (2mg AFs suspended in 5ml DMSO/ kg B.W.) }+3 \% \text { banana peel twice/ } \\
\text { week }\end{array}$ \\
\hline
\end{tabular}

\section{$\underline{\text { Results and Discussion }}$}

Isolation and identification of fungi from raw peanut seeds

The data revealed that 80 colony forming units (cfu) were totally isolated from raw peanut seeds by dilution $\left(10^{-3}\right)$ which are belonging to nine species. Aspergilli were the most frequent genera in peanut and accounted for $67.5 \%$ of total isolates. It constitutes 4 different species: Aspergillus flavus, A. parasiticus, A. niger and $A$. fischerianus. Aspergillus flavus was particularly prevalent on the isolation plates with high relative density $37.5 \%$ of total isolates. A. parasiticus came next in the dominance rank, representing $21.25 \%$ while, Eurotium amsteodami occupied the third rank in dominance with $12.5 \%$ of the total isolation. The other species were isolated occasionally with frequency of $6.25 \%$ or less. They were arranged descendingly as Aspergillus niger $>$ Penicillium funiculosum $>$ Mucor racemosus $>$ Rhizopus stolonifer $>$ Rhizopus oryzae $>$ Aspergillus fischerianus (Fig. 1).

In accordance with this results Zhang et al. (2017) concluded that Aspergillus flavus was the dominant species in peanut soil fungal population in some zones of China which represented 94.2\% of all isolates. Allover the world, peanut is a suitable substrate for aflatoxins production. Out of total 54 fungal isolates from infected peanut, 47 were found to be aspergilli and 31 of them were $A$. flavus (Jogee et al., 2017). Moreover Oyedele et al. (2017) reported that the incidence of aflatoxinproducing A. flavus in groundnuts was found to be $71 \%$ in Nigeria. In Brazil, A. flavus was the most frequent species of the genus Aspergillus in soil samples from four peanut production regions (Atayde et al., 2012). In Argentina, Aspergillus population recovered from peanut seeds showed A. flavus as the most frequently isolated species (79\%) (Nesci et al., 2011). Almost the same results were recorded in Egypt and the majority of Aspergillus isolates from peanut soil was aflatoxigenic (Embaby \& Abdel-Galel, 2014 and Sultan \& Magan, 2010).

Molecular identification for the most frequent A. flavus was performed with PCR as $481 \mathrm{bp}$. The resulting output showed the best similarity matches with the sequences of $A$. flavus available in databases at different homology coefficient level between 99 and 100\%. The obtained nucleotide sequence was deposited in NCBI GenBank and was given a species identifier, $A$. flavus with accession number MH189407 as shown in the phylogenetic tree constructed using MEGA 6 software (Fig. 2).

Identification of Aspergillus flavus aflatoxins using HPLC

Determination of aflatoxins in culture filtrate of Aspergillus flavus were estimated using HPLC chromatogram. The results showed that Aspergillus flavus produced four types of aflatoxins B1, B2, G1 and G2 at retention times $6.060 \mathrm{~min}, 4.794 \mathrm{~min}, 3.823 \mathrm{~min}$ and $3.084 \mathrm{~min}$, respectively. The excitation and emission wavelengths were 362 and 460nm (Florescence detector), respectively (Fig. 3).

In vitro adsorption of aflatoxins by banana peel

The results showed that, as the concentration of banana peel and the contact time with AFs were increased, the adsorption capacity increased. The highest reduction value in aflatoxins concentration in the solution was attained at $3.0 \%$ banana peel in presence of low concentration of aflatoxins at contact time $2 \mathrm{~h}$, where the adsorption of aflatoxins reached $(100 \%)$. The lowest value of aflatoxins adsorption $(24.2 \%)$ was obtained at $0.5 \%$ banana peel with the highest aflatoxins concentration after 1 h contact time (Table 2). 


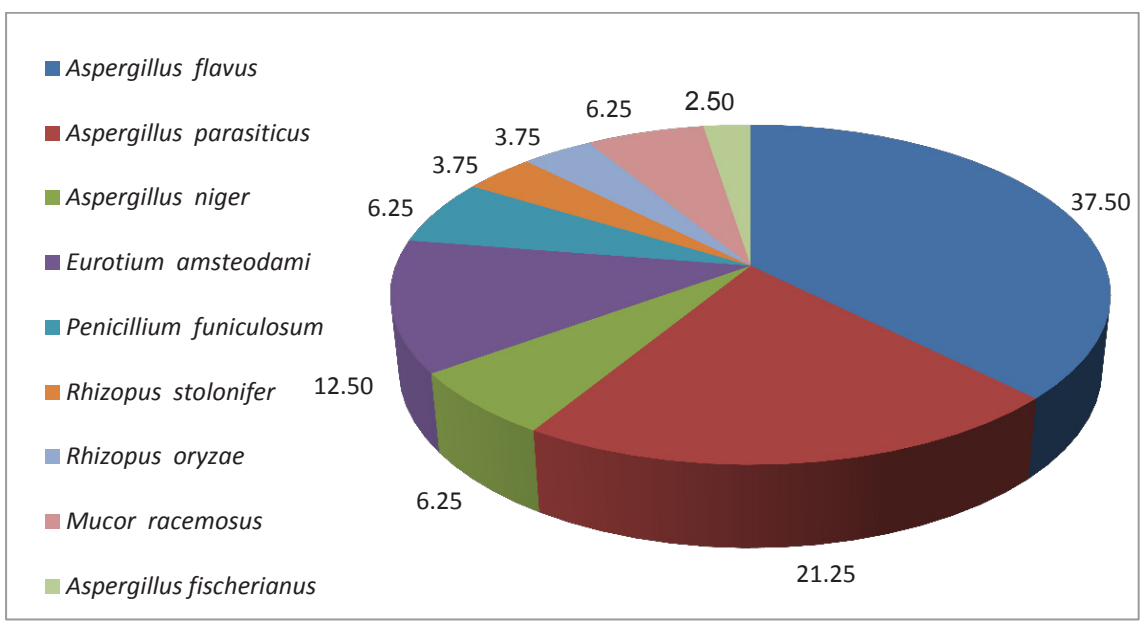

Fig. 1. Relative density (\%) of fungal species compared to total isolates.

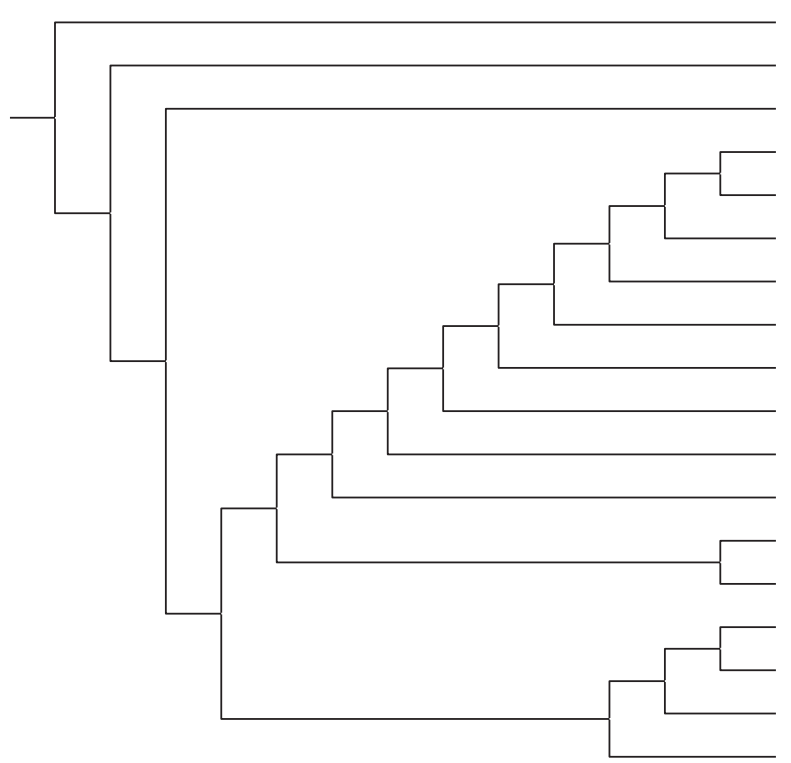

Aspergillus flavus (EU833206.1)

Aspergillus flavus (AB369896.1)

unknown(Query_83919)

Aspergillus fla vus (KT899781.1)

Aspergillus fla vus (KY260677.1)

Aspergillus fla vus (KY260658.1)

Aspergillus fla vus (KY065346.1)

Aspergillus fla vus (LC325163.1)

Aspergillus fla vus (LC325161.1)

Aspergillus fla vus (MF980914.1)

Aspergillus fla vus (MF166768.1)

Aspergillus fla vus (MF120213.1)

Aspergillus flavus (KY933394.1)

Aspergillus fla vus (KX067887.1)

Aspergillus flavus (KX067886.1)

Aspergillus fla vus (KX067885.1)

Aspergillus flavus (KX067877.1)

Aspergillus flavus (KX067853.1)

Fig. 2. Phylogenetic tree showing genetic relationship between the outlined isolate Aspergillus flavus and other closely related reference microorganisms.

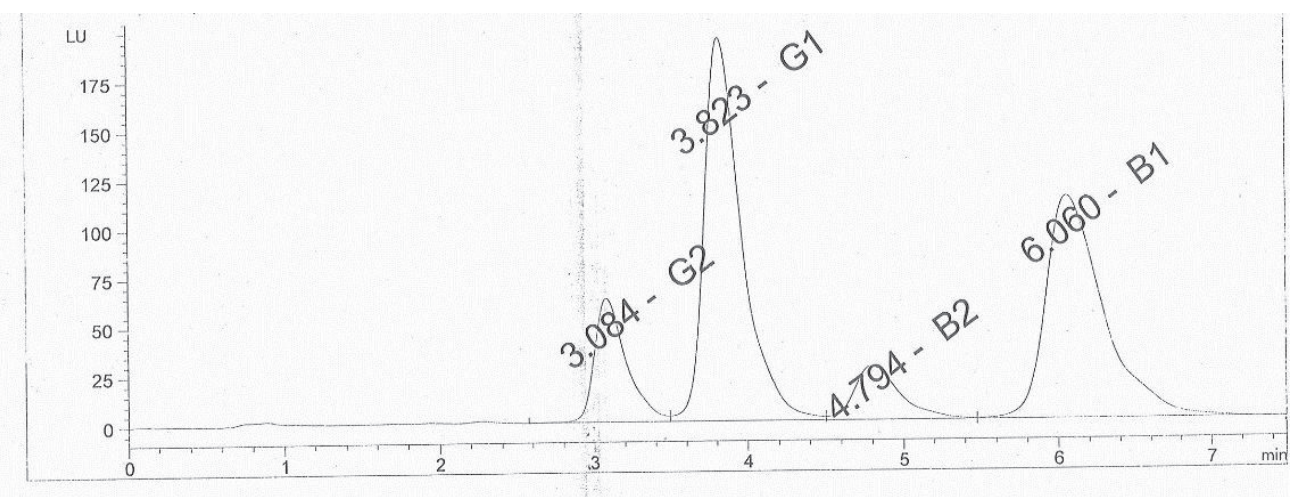

Fig. 3. HPLC Chromatogram for Aspergillus flavus aflatoxins showing the presence of AFB1, AFB2, AFG1 and AFG2. 
TABLE 2. Adsorption of aflatoxins by banana peel at different concentrations.

\begin{tabular}{|c|c|c|c|c|c|c|c|c|}
\hline \multirow{2}{*}{ AFs conc } & \multicolumn{8}{|c|}{ Remaining aflatoxins after adsorption } \\
\hline & \multicolumn{2}{|c|}{ (1) } & \multicolumn{2}{|c|}{ (2) } & \multicolumn{2}{|c|}{ (3) } & \multicolumn{2}{|c|}{ (4) } \\
\hline & 1 & 2 & 1 & 2 & 1 & 2 & 1 & 2 \\
\hline \multicolumn{9}{|l|}{ BP conc. } \\
\hline 0.0 & \multicolumn{2}{|c|}{ 1080ppb } & \multicolumn{2}{|c|}{ 1158ppb } & \multicolumn{2}{|c|}{ 1191.6ppb } & \multicolumn{2}{|c|}{ 1436.3ppb } \\
\hline 0.5 & $352.6^{\mathrm{G}}$ & $237.3^{\mathrm{M}}$ & $540.6^{\mathrm{D}}$ & $304.6^{\mathrm{K}}$ & $588.6^{\mathrm{C}}$ & $352.6^{\mathrm{G}}$ & $1089.6^{\mathrm{A}}$ & $688.6^{\mathrm{B}}$ \\
\hline 1.0 & $312^{\mathrm{J}}$ & $175.3^{\mathrm{R}}$ & $348.3^{\mathrm{H}}$ & $182.3^{\mathrm{MN}}$ & $451.6^{\mathrm{F}}$ & $216^{\mathrm{N}}$ & $536.3^{\mathrm{E}}$ & $277.3^{\mathrm{L}}$ \\
\hline 1.5 & $158.6^{\mathrm{U}}$ & $103.3^{Z}$ & $165.6^{\mathrm{T}}$ & $146.3^{\mathrm{w}}$ & $186.6^{\circ}$ & $172.6^{\mathrm{S}}$ & $325.6^{\mathrm{I}}$ & $177.6^{\mathrm{Q}}$ \\
\hline 2.0 & $112^{\mathrm{Y}}$ & $70.3^{d}$ & $121.3^{\mathrm{x}}$ & $80.3^{\mathrm{C}}$ & $182.3^{\mathrm{P}}$ & $110.3^{\mathrm{Y}}$ & $216.3^{\mathrm{N}}$ & $167.3^{\mathrm{T}}$ \\
\hline 2.5 & $86.3^{b}$ & $69.6^{\mathrm{d}}$ & $98.3^{a}$ & $69.6^{\mathrm{d}}$ & $157.6^{\mathrm{U}}$ & $104.3^{\mathrm{Z}}$ & $178.3^{Q}$ & $153.3^{\mathrm{V}}$ \\
\hline 3.0 & $7.3^{\mathrm{i}}$ & $0.0^{\mathrm{j}}$ & $44.6^{\mathrm{f}}$ & $14.3^{\mathrm{h}}$ & $53.3^{\mathrm{e}}$ & $16.6^{\mathrm{g}}$ & $120^{x}$ & $54.6^{\mathrm{e}}$ \\
\hline
\end{tabular}

The various superscript letters in each parameter indicate statistically significant differences in the Duncan test, at $\mathrm{P}<0.05$, the least significant difference (LSD) was calculated at 95\% confidence interval. Banana peel (BP), Aflatoxins concentrations (AF conc), Concentrations of aflatoxins: 1(1080 ppb), 2(1158 ppb), 3(1191.6 ppb) and 4(1436.3 ppb).

High ability of banana peel powder as an adsorbent to remove of anionic dyes from aqueous solution was reported by Munagapati et al. (2018). They also concluded that the adsorption increases by increasing contact time because banana peel has an irregular and porous surface which is adequate for adsorption. Oyewo et al. (2016) indicated that nanostructured banana peels are a potential adsorbent for the removal of radioactive substances from aqueous solution and from real mine water. Mohammed \& Chong (2014) concluded that the waste banana peel is a promising material for the biological treatment of Palm Oil Mill Effluent. Banana peel is a high economically viable and low-cost adsorbent for copper removal (Hossain et al., 2012). Adsorbent effect of pomegranate peel in removal of aflatoxins in vitro revealed a gradual increase in aflatoxins adsorption efficiency of dried pomegranate peel in all used aflatoxin concentrations (Abo Haggar, et al., 2009).

Histological alterations in liver and kidney of albino rats treated with aflatoxin singly or in combination with banana peel powder:

\section{Liver study}

Liver sections revealed no pathological alterations were observed in the untreated control group as their liver showed normal hepatocytes separated by blood sinusoids around the portal tract (PT) and the central vein (CV) (Fig.4- G1). However, the liver of rat groups treated with either low or high doses of aflatoxins showed expanded portal tract with inflammatory cells and fibrosis in low dose AFs which increase in high dose of AFs with an increase in degenerated hepatocytes in portal area (Fig. 4- G2 and G3). A section in the liver of albino rat received banana peel (3\%) showing normal hepatocytes without any sign of histological alterations (Fig. 4- G4). However, section in the liver of a rat received banana peel 3\% with low dose of aflatoxin showing an improvement in the vacuolar damage and in the inflammation of hepatocytes (Fig. 4- G5). Moreover, section in the liver of a rat received banana peel $3 \%$ with high dose of aflatoxin showing an improvement, but to less extend, in hepatocytes architecture and vacuolar damage (Fig. 4- G6).

\section{Kidney study}

Histopathological examination of kidney showed that the kidney is less sensitive to the harmful effect of aflatoxins than liver. No pathological alterations were observed in kidney of control group as it showed normal glomeruli and renal tubules (Fig. 5- G1). Whereas, section in the kidney of a rat received low dose of AFs showing expanded glomeruli with hyper cellularity and vacuolation. Some tubules are damaged or 
showing cytoplasmic vacuolation and pyknotic nuclei (Fig.5- G2). A section in the kidney of a rat received high dose of AFs showing vacuolar and fatty degeneration in the renal tubular epithelial cells, hyaline cast, interstitial inflammation and hyperplastic changes in glomeruli (Fig. 5- G3). A section in the kidney of a rat received banana peel 3\% showing nearly normal renal tubules and glomeruli (Fig. 5- G4). However, section in the kidney of a rat received banana peel 3\% with low dose of aflatoxins showing dilatation in the renal tubular lumen and low interstitial inflammation with hyperplastic changes in glomeruli (Fig. 5- G5). Whereas, section in the kidney of a rat received banana peel 3\% with high dose of aflatoxins showing injury in the renal tubular epithelial cells with increase in interstitial inflammation with normal Bowman's capsule and urinary spaces of glomeruli (Fig. 5- G6)

The liver is very important organ of human
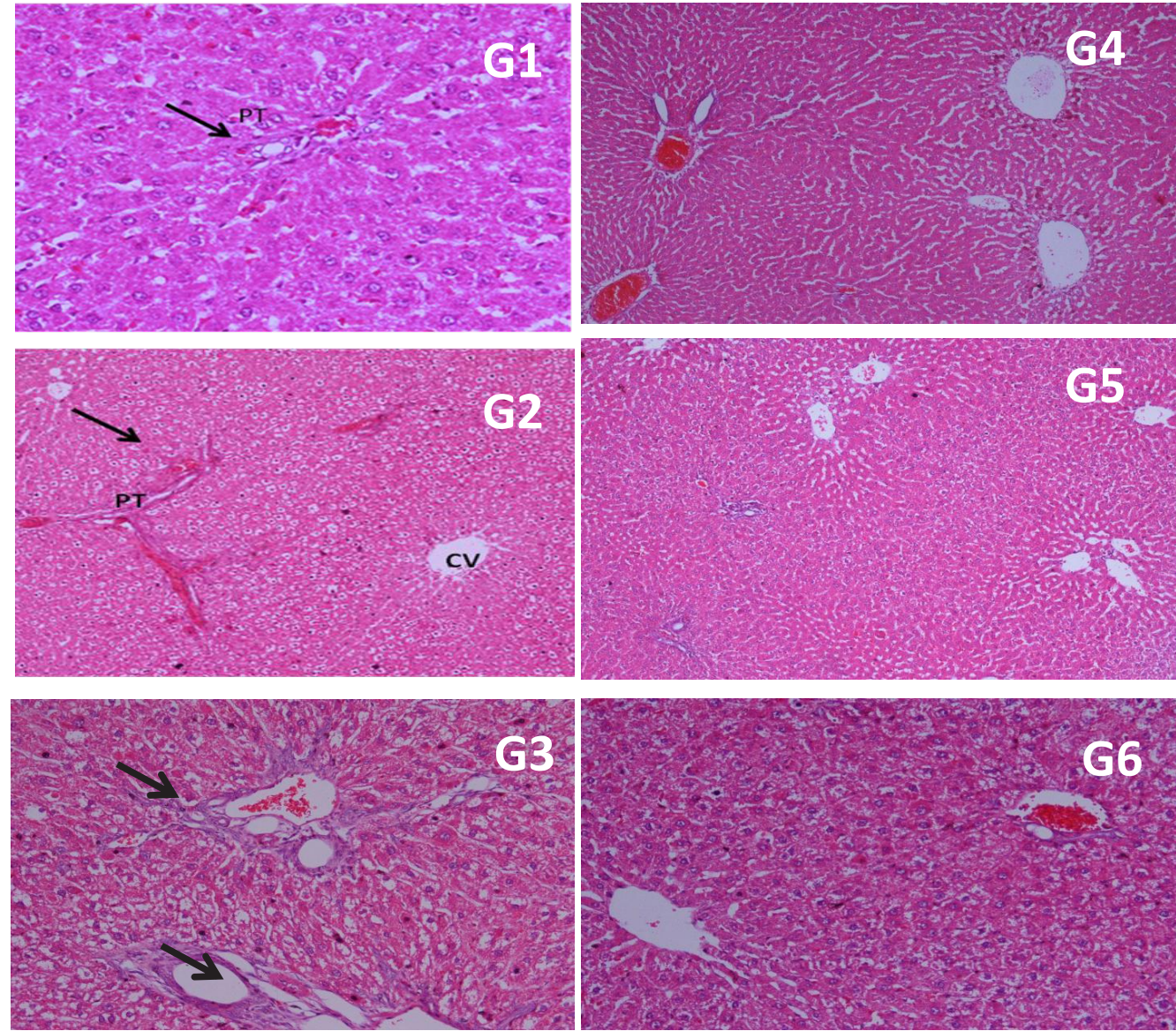

Fig. 4 (G1-G6). Sections in the liver of albino rat control group (G1), groups treated with low and high AFs doses (G2 amd G3) respectively, group treated with banana peel singly (G4) and groups treated with banana peel in combination with low or high AFs doses (G5 and G6) respectively [HX\&E x100 for G2 and G6 while it is $\times 200$ for $\mathbf{G 1}, \mathbf{G 3}, \mathbf{G} 4$ \& $\mathrm{G5}$ ].

Egypt. J. Bot. 59, №. 2 (2019) 

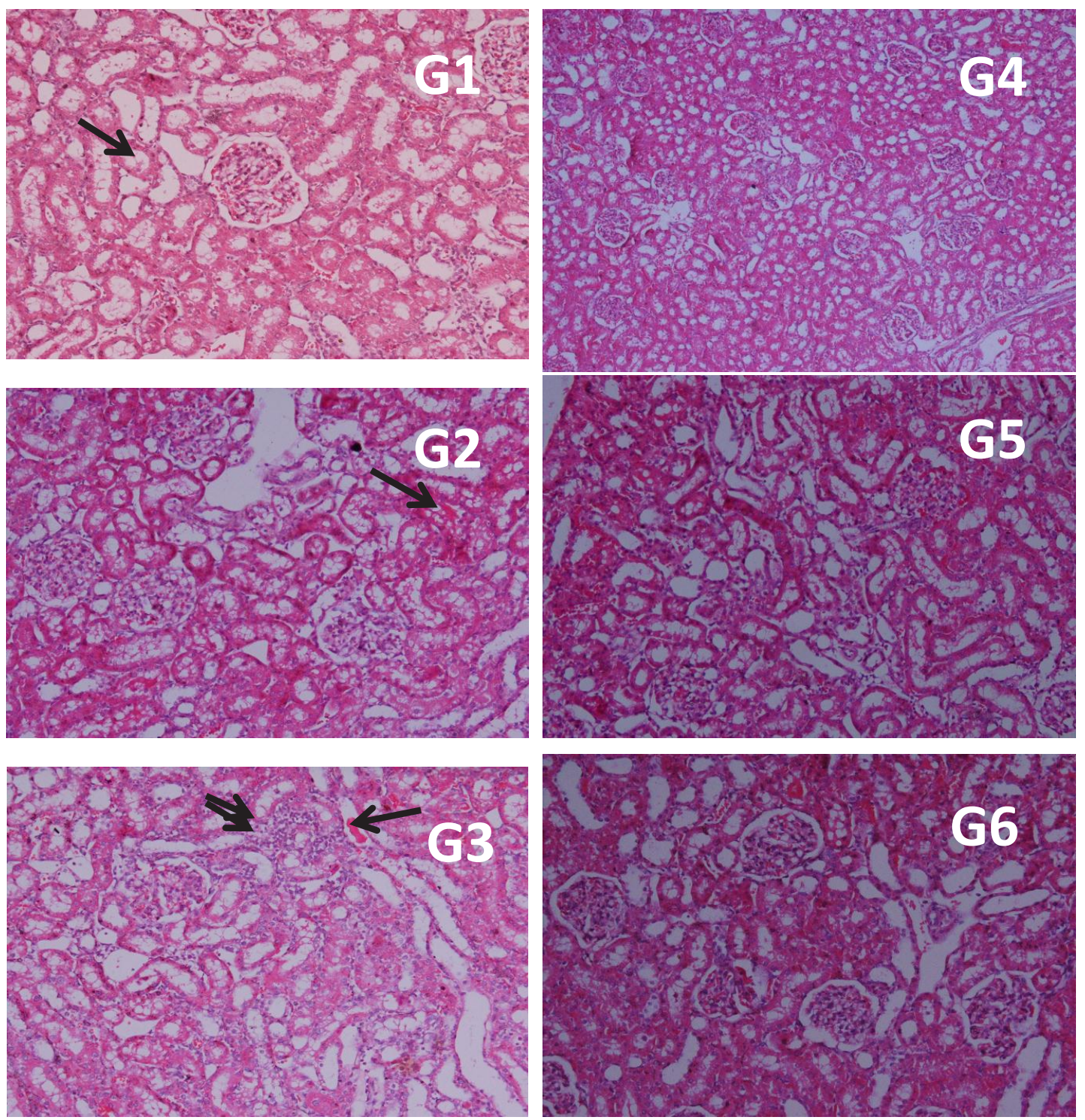

Fig. 5 (G1-G6). Sections in the kidney of albino rat control group (G1), groups treated with low and high AFs doses (G2 and G3) respectively, group treated with banana peel singly (G4) and groups treated with banana peel in combination with low or high AFs doses (G5 \& G6) respectively [HX\&E x 200].

In the present study the microscopic appearance of the liver by feeding aflatoxins showed histological alteration including portal and parenchymatous degeneration, hepatocytes necrosis as well as the blood vessels congestion were increased by increasing level of aflatoxins. Hasan (2014) found similar results in liver of rats during feed on stored walnuts contaminated with aflatoxins. Almost these alterations were similar to those reported by Pazani et al. (2008), Rawal et al. (2010), Ogunjobi et al. (2012), Kana et al. (2014) and Ibrahim (2013). Magnoli et al. (2011) and Ahmed et al. (2009) found that there were histological alterations in broiler liver tissues when treated with monensin and sodium bentonite. Saleh et al. (2016) reported that inflammation, vacuolation of hepatocyte in liver and vacuolation of cortical tubules, areas of necrotic cortical tubules in kidney of pigeon were shown as a result of aflatoxin contamination of diet. El-Bahr et al. (2015) found that curcumin induce toxicity of aflatoxin B1 in rats and cause some pathological alterations in rats' liver.

Onyegeme-Okerenta Blessing \& Enyadike 
Nelson (2015) claimed that when wistar albino rats treated with aflatoxin contaminated agro-feeds, liver and kidney alterations were recorded. Tohame et al. (2010) recorded that pomegranate peel extract was able to protect liver and kidney tissue against low AFs dose and minimize the damage of liver and kidney induced by high AFs dose. Y1lmaz et al. (2017) recommended that vitamin $\mathrm{E}$ can be regarded as a good therapeutic agent against aflatoxicosis. Shahat et al. (2017) found damage effects of aflatoxins in liver and kidney tissues so they used ozone to reduce this effect.

\section{Conclusion}

Peanut seeds are contaminated with aflatoxigenic A. flavus which produce four types of aflatoxins. Banana peel powder could adsorb AFs in the diet of albino rat and reduce its injury either in liver or in kidney. Banana peel is inexpensive, safe and available in large quantities all the year.

\section{$\underline{\text { References }}$}

Abd El-Mageed, F.A. (1987) Some biological and nutritional studies on aflatoxins. M.Sc. Thesis, Zagazig Univ., Fac. Agric., Egypt.

Abdel-Wahhab, M.A., Sehab, A.F., Hassanien, F.R., ElNemr, Sh.E., Amra, H.A. and AbdelAlim, H. (2011) Efficacy of ozone to reduce fungal spoilage and aflatoxin contamination in peanuts. International Journal of Nuts and Related Sciences, 2, 1-14.

Abdel-Rahman, Tahany M., Dalia, M.I.A., Abo Haggar, A. and Mona S.A. (2017) Efficacy of banana peel in reduction of aflatoxin toxicity in rats. J. Agric. Chem. Biotechn., Mansoura Univ. 8, 251-259.

Abo Haggar, A., El moghazy, G.M. and Atwa, M.A. (2009) Use of pomegranate peel as antifungal and adsorbent material for removal of total aflatoxins (in vitro). J. Agric. Sci., Mansoura Univ., 34, 77-85.

Ahmed, M.A.E., Ravikanth, K., Rekhe, D.S. and Maini, S. (2009) Histopathological alterations in aflatoxicity and its amelioration with herbomineral toxin binder in broilers. Veterinary World, 2, 390-392.

Ahsan, M.R., Islam, K.M., Bulbul, I.J., Musaddik, M.A. and Haque, E. (2009) Hepatoprotective activity of methanol extract of some medicinal plants against carbon tetrachloride-induced hepatotoxicity in rats. Eur. J. Sci. Res. 37, 302-310.
AOAC (2016) "Official Methods of Analysis", $20^{\text {th }}$ ed., no.991.31. Chapter 49.

Asim, M., Sarma, M.P., Thayumanavan, L. and Kar, P. (2011) Role of aflatoxin B1 as a risk for primary liver cancer in north Indian population. Clinical Biochemistry, 44, 1235-1240.

Atayde, D.D., Reis, T.A., Godoy, I.J., Zorzete, P., Reis, G.M. and Corrêa, B. (2012) Mycobiota and aflatoxins in a peanut variety grown in different regions in the state of são paulo, Brazil. Crop Protect. 33, 7-12.

Bancroft, J.D. and Stevens, A. (1996) "Theory and Practice of Histological Techniques". $4^{\text {th }}$ ed., Ch. 6, p.99.

Barnett, H.L. and Hunter, B.B. (1972) "Illustrated Genera of Imperfect Fungi". Burgess Publishing Company, Minneapolis, Minnesata, USA.

Chabuck, Z.A.G., Al-Charrakh, A.H., Hindi, N.K.K. and Hindi, S.K.K. (2013) Antimicrobial effect of aqueous banana peel extract, Iraq. Research Gate: Pharmaceutical Sciences, 1, 73-75.

Chanda, S., Baravalia, Y., Kaneria, M. and Rakholiya, K. (2010) Fruit and vegetable peels- strong natural source of antimicrobics. "Current Research, Technology and Education Topics in Applied Microbiology and Microbial Biotechnology", A. Mendez-Vilas (Ed.). pp. 444-450.

Cheng, J.I., Fan, Y. and Zhao, L. (2016) Review on biological degradation of mycotoxins. Animal Nutrition, 2, 127-133.

Choi, K.C., Chung, W.T., Kwon, J.K., Jang, Y.S., Yu, J.Y. and Park, S.M. (2011) Chemoprevention of aflavonoid fraction from Rhus verniciflua Stokes on aflatoxin B1-induced hepatic damage in mice. $J$. Appl. Toxicol. 31, 150-156.

Clifford, J.I. and Rees, K.R. (1966) Aflatoxin a site of action in the rat liver cell. Nature, 209, 312-313.

Das, N., Vimala, R. and Khartika, P. (2008) Biosorption of Heavy Metals: An overview. Indian Journal of Biotec. 7, 159-169.

Devendran, G. and Balasubramanian, U. (2011) Biochemical and histopathological analysis of aflatoxin induced toxicity in liver and kidney of rat. Asian J. Plant Sci. Res. 1, 61-69. 
El-Bahr, S.M., Embaby, M.A., Al-Azraqi, A.A., Abdelghany, A.M., Hussein, Y.A., AL Hizab, F.A. and Althnaian, T.A. (2015), Effect of curcumin on aflatoxin B1-induced toxicity in rats: A Biochemical and histopathological study. International Journal of Biochemistry Research\& Review, 5, 63-72.

Embaby, E.M. and Abdel-Galel, M.M. (2014) Detection of fungi and aflatoxins contaminated peanut samples (Arachis hypogaea L.). Journal of Agricultural Technology, 10, 423-437.

Farombi, E.O., Adepoju, B.F., Ola-Davies, O.E. and Emerole, G.O. (2005) Chemoprevention of aflatoxin B1-induced genotoxicity and hepatic oxidative damage in rats by kolaviron, anatural biflavonoid of Garcinia kola seeds. Eur. J. Cancer Prev. 14, $207-$ 214.

Gilman, J.C. (1957) "A Manual of Soil Fungi", The Iowa State University Press, Ames, Iowa, USA.

Gonçalez, E., Pinto, M.M. and Felicio, J.D. (2001) Análise de micotoxinas no InstitutoBiológico de 1989-1999. Biológico, 63, 15-19.

Guchi, E. (2015) Implication of aflatoxin contamination in agricultural products. American Journal of Food and Nutrition, 1, 12-20.

Gyamfi, M.A. and Aniya, Y. (1998) Medicinal herb, Thonningia sanguinea protects against aflatoxin B1 acute hepatotoxicity in Fischer 344 rats. Hum. Exp. Toxicol. 17, 418-423.

Hasan, R.H.G. (2014) Acute and chronic effects of aflatoxin on the liver of rats during the storage of walnuts. World Applied Sciences Journal, 31, 12691277.

Hossain, M.A., Ngo, H.H., Guo, W.S. and Nguyen, T.V. (2012) Removal of copper from water by adsorption onto banana peel as bioadsorbent. Int. J. of Geomate, 2, 227-234.

Ibrahim, Q.Q. (2013) Histopathological study of quail silver experimentally induced by aflatoxin. Bas. J. Vet. Res. 12, 116-127.

Janjua, S., Shahid, M. and Abbas, F.I. (2013) Phytochemical analysis and in vitro antibacterial activity of root peel extract of Raphanus sativus L. var niger. Advancement in Medicinal Plant Research, 1, 1-7.
Jogee, P.S., Ingle, A.P. and Rai, M. (2017) Isolation and identification of toxigenic fungi from infected peanuts and efficacy of silver nanoparticles against them. Food Control, 71, 143-151.

Kamba, A.S. and Hassan, L.G. (2010) Phytochemical screening and antimicrobial activities of African star apple (Crysopyllum albidum) leaves, stem against some pathogenic microorganisms. International Journal of Pharmaceutical Frontier Research, 1, 119-129.

Kana, J.R., Ngoula, F., Tchoffo, H., Tadondjou, C.D., Sadjo, Y.R., Teguia, A. and Gnonlonfin Gbemenou, J.B. (2014) Effect of biocharcoals on hematological, serum biochemical and histological parameters in broiler chickens fed aflatoxin B1contaminated diets. Journal of Animal Science Advances, 4, 939- 948.

Kulkarni, A.P. (2005) Bioactive molecules from pomegranate fruit waste (pith and carpellary membrane). Ph.D Thesis. Department of Fruit and Vegetable Technology, Central Food Technological Research Institute, Mysore.

Lafi, S.A., Taha, N.A. and Al-Genabi, S.M.H. (2010) Histopathology of the liver affected with aflatoxins in broiler chicks. Al-Anbar J.Vet.Sci. 3, 115-119.

Liu, T.Y., Hwua, Y.S., Chao, T.W. and Chi, C.W. (1995) Mechanistics study of the inhibition of aflatoxin B1-induced hepatotoxicity by dimethyl-4,4dimethoxy-5,6,5,6- dimethylene-dioxybiphenyl2,2-dicarboxylate. Cancer Lett. 89, 201-205.

Magnoli, A.P., Monge, M.P., Miazzo, R.D., Cavaglieri, L.R., Mangoli, C.E., Merkis, C.I., Cristofolini, A.L., Dalcero, A.M. and Chiacchiera, S.M. (2011) Effect of low levels of aflatoxin B1 on performance, biochemical parameters and aflatoxin $\mathrm{B} 1$ in broiler liver tissues in the presence of monensin and sodium bentonite. Poult. Sci. 90, 48-58.

Mandi, L., Achak, M., Hafidi, A. and Ouazzani, N. (2009) Low cost bio-sorbent for the removal of phenolic compounds from olive mill wastewater. Options MÈ diterranÈennes, Technological Perspectives for Rational Use of Water Resources in the Mediterranean Region, 88, 179-186.

Mane, R.S. and Bhusari, V.N. (2012) Removal of colour (dyes) from textile effluent by adsorption using orange and banana peel. International Journal of 
Engineering Research and Applications, 2, 19972004.

Memon, R., Jamil, Saima Q., Memon, Muhammad I. Bhanger and Muhammad, Y. Khuhawar (2008) Banana peel: A green and economical sorbent for Cr (III) removal. Pak. J. Anal. Environ. Chem. 9, 20-25.

Mohamed, S., Hassan, Z. and Hamid, N.A. (1994) Antimicrobial activity of some tropical fruit wastes (guava, starfruit, banana, papaya, passionfruit, langsat, duku, rambutan and rambai). Pertanika Journal of Tropical Agriculural Science, 17, 219227.

Mohammed, R.R. and Chong, M.F. (2014) Treatment and decolorization of biologically treated palm oil mill effluent (POME) using banana peel as novel biosorbent. Journal of Environmental Management, 132, 237-249.

Mohd, A.K.R., Che, A.A.B. and Abdul, M.A. (2012) Antibacterial activity of flesh and peel methanol fractions of red pitaya, white pitaya and papaya on selected food microorganisms. International Journal of Pharmacy and Pharmaceutical Sciences, 4, 185-190.

Mopoung, S. (2008) Surface image of charcoal and activated charcoal from banana peel. Journal of Microscopy Society of Thailand, 22, 15-19.

Moubasher, A.H. (1993) "Soil Fungi in Qatar and Other Arab Countries". Scientific and Applied Research Center, University of Qatar.

Munagapati, V.S., Yarramuthi, V., Kim, Y., Lee, K. M. and Kim, D. (2018) Removal of anionic dyes (Reactive black 5 and Congo red) from aqueous solutions using banana peel powder as an adsorbent. Ecotoxicology and Environmental Safety, 148, 601-607.

Nesci, A., Montemarani, A. and Etcheverry, M. (2011) Assessment of mycoflora and infestation of insects, vector of Aspergillus section flavi, in stored peanut from Argentina. Mycotoxin Res. 27, 5-12.

Nierman, W.C., Cleveland, T.E., Payne, G.A., Keller, N.P., Campbell, B.C., Bennett, J.W., Guo, B., Yu, J. and Robens, J.F. (2008) Mycotoxin production and prevention of aflatoxin contamination in food and feed. In: "The Aspergilla Genomics, Medical
Aspects, Biotechnology, and Research Methods", Goldman, G.H. and Osmani, S.A. (Ed.), pp. 457472. Boca Raton: CRC Press.

NMKL report No.98, $4^{\text {th }}$ edition $(2005)$ Enumeration of yeast and mould in feed additives.

Ogunjobi, A.A., Owoseni, M.C., Bello, O.S., Ewuolo, E.O. and Adeleke, A.J. (2012) Growth performance and survival rate of Clarias gariepinus juveniles fed different levels of aflatoxin-contaminated feeds. Bull. Anim. Health Prod. Afr. 60, 519-529.

Oluwafemi, F. and Taiwo, V.O. (2004) Reversal of toxigenic effects of aflatoxin B1 [on cockerelsby alcoholic extract of African nutmeg, Monodora myristica. J. Sci. Food Agric. 84, 333-340.

Onyegeme-Okerenta Blessing, M. and Enyadike Nelson, U. (2015) Hepatotoxic effect of aflatoxincontaminated agro feeds (groundnut, maize and melon seed) on Wistar albino rats. Agricultural and Biological Sciences Journal, 1, 190-196.

Oyedele, O.A., Ezekiel, C.N., Sulyok, M., Adetunji, M.C., Warth, B., Atanda, O.O. and Krska, R. (2017) Mycotoxin risk assessment for consumers of groundnut in domestic markets in Nigeria. International Journal of Food Microbiology, 251, 24-32.

Oyewo, O.A., Onyango, M.S. and Wolkersdorfer, C. (2016) Application of banana peels nanosorbent for the removal of radioactive minerals from real mine water. Journal of Environmental Radioactivity, 164, 369-376.

Park, J.W., Kim, E.K., Shon, D.H. and Kim, Y.B. (2002) Natural co-occurrence of aflatoxin B1, fumonisin B1 and ochratoxin A in barley and corn foods from Korea. Food Addit. Contam. 19, 1073-1080.

Pazani, J., Marandi, M.V., Ashrafilhelan, J., Marjanmeher, S.H. and Ghods, F. (2008) Pathological studies of A/chicken/Tehran/ZMT-173/99 (H9N2) influenza virus in commercial broiler chickens of Iran. Int. J. Poult. Sci. 7, 502-510.

Prabu, P.C., Dwivedi, P. and Sharma, A.K. (2013) Toxicopathological studies on the effects of aflatoxin B1, ochratoxin A and their interaction in New Zealand White rabbits. Experimental and Toxicologic Pathology, 65, 277-286. 
Raper, K.B. and Fennell D.I. (1965) "The Genus Aspergillus". The Williams and Wilkins Company, Baltimore, MD, USA.

Rawal, S., Kim, J.E. and Coulombe, J.R. (2010) Aflatoxin B1 in poultry: Toxicology, metabolism and prevention. Res. Vet. Sci. 89, 325-331.

Roos, A.H., Van der Kamp, H.J. and Marley, E.C. (1997) Comparison of immunoaffinity columns with Florisil/ C18 columns for the determination of aflatoxins in animal feed and maize. Mycotoxin Research, 13, 1-10.

Salah, S.M. (2012) Antibacterial activity and UV protection property of some Egyptian cotton fabrics treated with aqueous extract from banana peel. International Journal of Clothing Science, 1, 1-6.

Saleh, M.K., Bahaa, A.A. and Yaser, I.H. (2016) Toxicological pathology of aflatoxin B1 in local pigeon mainly in liver, kidney and heart. Journal of International Academic Research for Multidisciplinary, 4, 218-227.

Samson, R.A. (1979) A compilation for the Aspergilli described since 1965. Studies in Mycology, 18, 1- 40.

Samson, R.A., Hoekstra, E.S., Frisvad, J.C. and Filtenborg, O. (1995) "Introduction to Food-born Fungi", $4^{\text {th }}$ ed. Wageningen, the Netherlands.

Samson, R., Houbraken, J., Thrane, U., Frisvad, J.C. and Andersen, B. (2010) "Food and Indoor Fungi". CBS-KNAW Fungal Biodiversity Centre, Utrecht, the Netherlands.

Shahat, M.S., Badr, A.N., Hegaziy, A.I., Ramzy, S.H. and Abdel Samie, M. (2017) Reducing the histopathological and biochemical toxicity of aflatoxins contaminated soybean using ozone treatment. Annual Research \& Review in Biology, 15, 1-10.

Shotwell, O.L., Hesseltine, C.W., Stubblefield, R.D. and Sorenson, W.G. (1966) Production of aflatoxin on rice. Appl. Microbiol. 14, 425-428.

Snedecor, G.W. and Cochran, W.G. (1994) "Statistical Methods". $9^{\text {th }}$ ed. Iowa State Univ. Press, Ames, Iowa, USA.
Sultan, Y. and Magan, N. (2010) Mycotoxigenic fungi in peanuts from different geographic regions of Egypt. Mycotoxin Research, 26, 133-140.

Tohame, A.A.T., Abo-Hagger, A.A. and Abd El-Shafea, Y.M. (2010) Modulation of aflatoxins toxicity in rats by ethanolic pomegranate peel (Punica granatum L.) extract. J. Animal and Poultry Prod., Mansoura Univ. 1, 641-658.

Velmurugan, P., Rathina Kumar, P. and Dhinakaran, G. (2011) Dye removal from aqueous solution using low cost adsorbent. International Journal of Environmental Sciences, 1, 1492-1503.

Waller, R.A. and Duncan, D.B. (1969) A Bayes rule for symmetric multiple comparison problem. J. Am. State. Assoc. 64, 1484-1503.

Ward, F.M. and Dally, M.J. (2002) Hepatic disease. In: "Clinical Pharmacy and Therapeutic", Walker, R. and C. Edwards (Ed.), pp.195-212. Churchill living Stone, New York.

Watanabe, T. (2002) "Pictorial Atlas of Soil and Seed Fungi". Morphologies of Cultured and Key to Species. $2^{\text {nd }}$ ed. CRC Press. Boca Raton London New York Washington D.C.

Y1lmaz, S., Kaya, E. and Comakli, S. (2017) Vitamin E ( $\alpha$ tocopherol) attenuates toxicity and oxidative stress induced by aflatoxin in rats. Adv. Clin. Exp. Med. 26, 907-917.

Zhang, C., Selvaraj, J.N., Yang, Q. and Liu, Y. (2017) A survey of aflatoxin-producing Aspergillus sp. from peanut field soils in four agroecological zones of China. Toxins, 9, 1-14.

Zheng, H. and Wang, L. (2013) Banana peel carbon containing functional groups applied to the selective adsorption of $\mathrm{Au}$ (III) from waste printed circuit boards. Soft Nanoscience Letters, 3, 29-36.

(Received 10/11/2018; accepted 10/2/2019) 


\section{التقييم الحيوى والمعملى لمسحوق قثر الموز كمادة ماصة للأفلاتوكسينات}

داليا محمد إبراهيم على(1) ، تهانى محمد عبد الرحمن(1)، أمل عبد العزيز أبوحجر (2)و منى سعيد أحمد(2)

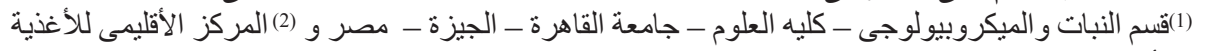

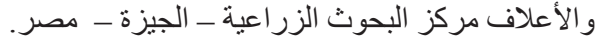

أدى مسح الفطريات من بذور الفول السودانى الخام بطريقة الغسيل إلى عزل تسعة أنواع فطرية وكانت فطرة

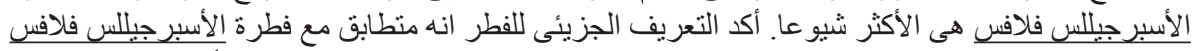

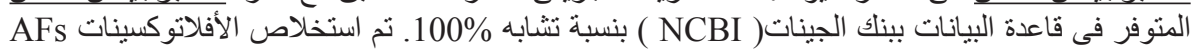

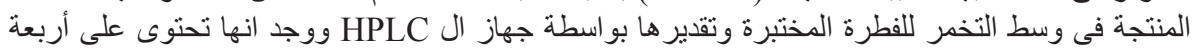

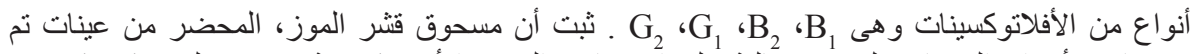

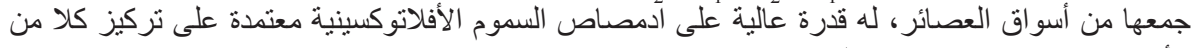

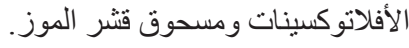

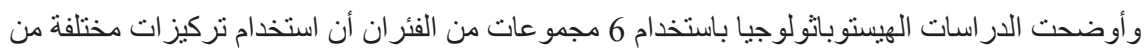

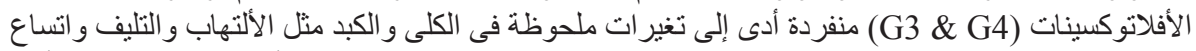

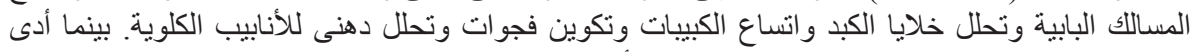

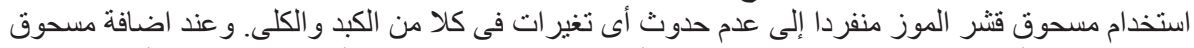

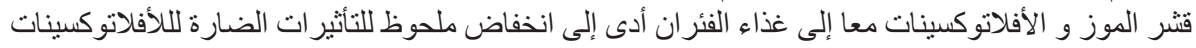

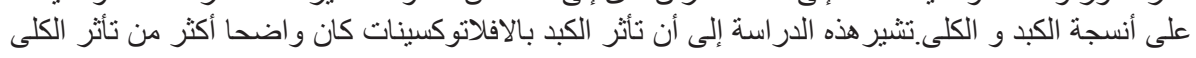

